\title{
LAW ENFORCEMENT THROUGH 'LUDRUK' AND CULTURAL ADVANCEMENT
}

\author{
Tomy Michael \\ Universitas 17 Agustus 1945, Surabaya \\ a_los_tesalonicenses@yahoo.com
}

ARTICLE INFORMATION

Article history:

Received Sept 01, 2017

Revised Dec 23, 2017

Accepted March 25, 2018

JEL Classifications

Z19; D73

Key Words:

Ludruk;

Culture;

Corruption

DOI:

10.21532/apfj.001.18.03.01.15

\begin{abstract}
The increasingly rampant corruption in Indonesia requires creative countermeasures. One way is to assimilate the law with the local culture of a region. The local culture concerned is ludruk. Ludruk, as one of Javanese traditional art performances, is admired by its fans or supporters in East Java and can be used as a means to proclaim everything about corruption. It can be concluded that the assimilation of the law with the local culture of a region is not contrary to the law but it is becoming a media in eradicating corruption. Anti-corruption teaching can be delivered through ludruk as long as it remains in accordance with the nature of ludruk itself.
\end{abstract}

\section{A. INTRODUCTION}

There should be a new paradigm of law enforcement to eradicate the increasingly massive corruption cases in Indonesia ${ }^{1}$. Referring to Corruption Perceptions Index 2016 , Indonesia is ranked $90^{\text {th }}$ with a score of 37 . This means the level of corruption is very high. ${ }^{2}$ When associated with the various tribes, religions, races and classes existing in Indonesia, the law enforcement should be implemented in

1 Referring to Article 1 Sub-Article 3, 4 and 5 of the Law of the Republic of Indonesia Number 28 of 1999 regarding the Implementation of Clean and Free State from Corruption, Collusion, and Nepotism (Law 28/2009) it is stipulated that:

a. Corruption is a criminal act as referred to in the provisions of laws and regulations governing the criminal act of corruption

b. Collusion is unlawful conspiracy or cooperation between the State Organizers or between the State Organizer and any other party that harms others, the public, and or the state

c. Nepotism is any unlawful act of the State Organizer that benefits the interest of his family and / or his cronies above the interests of society, nation and state

2 Accessed through www.transparency.org/cpi on August 27, 2017. 
accordance with the nature of such differences. One way is to do legal assimilation with local culture of each region. ${ }^{3}$

3 For comparison, in Hinduism, Pravrtti as an outward act is
physical action that only works to obtain physical things. The
concept of working in Pravrtti is to think of something that is
outwardly like working to earn a lot of money, the more you
work the more wealth you will gain. The more wealth, the more
things you have; the more things you really have, the more you
suffer. Moreover, work to take the rights of others, your sin
will be very large. In contrast to the Nivrtti concept, wherein
inner contemplation means that working to get nihsreyasa, the
spiritual freedom of all beings. Working into anything is a form
of devotion to God so that what is satisfied is the mind, not the
physic because if the mind is happy, there really is no need
for physical happiness anymore because the physical happiness
has actually been satisfied. The concept of work referred to in
Hinduism is to combine work according to Pravrtti and Nivrtti
that is to work for the well-being and happiness of the inner
or working without pressure and fear. In contrast to unbinding
work, all work is done for others and the common good and
all the work is done on the devotion to God so that welfare
and happiness are born inward. It is also the Bhagawadgita
recipe of unbinding work, first not to engage in the outcome,
the second is to work for the welfare of the people, essentially
working to achieve material prosperity (abhyudaya) and spiri-
tual fulfillment (nisreyasa). Bhagawadgita 2 , 47 mentions the following concepts of work:

Karmany evadhikaraste

Ma phalesu kadacana

Ma karma-phala-hetur bhur

Ma tesa sango 'stv akarmani

The translation:

"You are entitled to do your assigned duty, but you are not entitled to the result of the deed. Do not disturb yourself with the results of your activities, and do not be tied to the habit of not doing your duty."

Niyatam Kuru karma tvam

Karma jyayo hyakarmanah

Sarirayatrapi ca te

Na prasiddhyet akarmanah

The translation:

"Perform your assigned duties and obligations, for doing so is better than doing nothing. A person cannot even maintain his physical body without working."

Sreyan dravya-mayad yajnaj

Jnana-yajnah parantapa

Sarvam karmakhilam partha

Jnane parisamapyate

The translation:

"O enemy conquerors, sacrifices made with knowledge are better than sacrificing material possessions. $\mathrm{O}$ prtha son, however, all sacrifices consisting of work culminate in spiritual knowledge"

The concept of work in Hinduism, Pravrtti and Nivrtti, very clearly teaches not to commit corruption but to work without bond and all for the welfare of society. Whoever the ruler, please work for the welfare of the people, do not work for yourself and the group, and do not think about the work because the
Referring to Article 32 Paragraph (1) of the 1945 Constitution of the Republic of Indonesia, "The State promotes the national culture of Indonesia in the midst of world civilization by guaranteeing the freedom of the society in maintaining and developing its cultural values". Thus, in this study the researcher tries to promote law enforcement through ludruk as one way to eradicate corruption.

\section{B. LITERATURE REVIES AND DISCUSSION}

\section{The Nature of Ludruk as a Local culture}

The people of East Java have many traditional art performances that are still alive. They are proud of the traditional art performances. And some people have even utilized the performances for certain purposes. The traditional art performances have many heirs, both active heirs or artists and passive heirs or art connoisseurs. The living traditional art performances are broadly divided into two categories: agrarian arts and non-agrarian arts. Agrarian arts consist of tayub, sandur, seblang, gandrung, and reog, while non-agrarian arts consist of ludruk, wayang orang, kentrung, topengan, ketoprak, jinggoan, janger, and others. One form of agrarian art that is still alive and has a lot of active and passive heirs in East Java is reog Ponorogo, while for the non-agrarian art is in the form folk theater called ludruk. These two forms of traditional

results do not betray the process, do sincerely and all devoted on the basis of devotion to God. Always do the work calmly. Or by meditation, so that every decision made can strengthen the mental so as to be away from temptation. A Karma Yogi, Manava Seva or services to fellow human beings or even to fellow creatures is madhava Seva or devotion to the Almighty. Furthermore, in I Made Adi Surya Pradnya, "Konsep Pravrtti Dan Nivrtti, Strategi Mencegah Korupsi Di Perguruan Tinggi" in Prosiding Seminar Nasional Hukum Strategi Penanggulangan Korupsi Di Perguruan Tinggi, Law Faculty of Dharma Duta Institut Hindu Dharma Negeri Denpasar, May 12, 2017, p. 106-108. 
art performance have active and passive heirs scattered in various places. ${ }^{4}$

The word ludruk comes from the lower (ngoko) level of Javanese language in East Java which means clown. ${ }^{5}$ Etymologically, the word ludruk comes from the words molo-molo and gedrak-gedruk. Molo-molo means the mouth which is full of sugi tobacco (and the word "molo" means an activity in which at the time of speaking there is still tobacco losses in the speaker's mouth). The speaker is about to vomit the tobacco, then comes out the words of kidungan (a kind of hymn) and dialogue. While gedrak-gedruk means the pounding feet while

4 Ayu Sutarto, Reog Dan Ludruk: Dua Pusaka Budaya dari Jawa timur Yang Masih Bertahan, Makalah dalam Jelajah Budaya dengan tema: Pengenalan Budaya Lokal Sebagai Wahana Peningkatan Pemahaman Keanekaragaman Budaya, Yogyakarta 22-25 Juni 2009, p. 1.

Surabaya is a multi-ethnic city that is rich in cultural diversity. Various ethnic groups such as Malay, Chinese, Indians, Arabs and Europeans migrated to Surabaya. Various ethnic archipelago such as Madura, Sunda, Batak, Papua, Maluku, Borneo, Bali, and Sulawesi, also came and settled in the City of Heroes. They then mingled with the natives of Surabaya and formed a cultural diversity that later became the hallmark of the city of Surabaya. This is what distinguishes the city of Surabaya from other cities in Indonesia. Even the characteristic of cultural diversity is very strong coloring the daily life of Surabaya residents. Attitudes that are very egalitarian, open, frank, critic and criticize, is the attitude of life of Surabaya residents that can be encountered everyday. Even traditional art and traditional food reflect Surabaya's cultural pluralism. Art life in the city of Surabaya grow well. Traditional and modern art complement each other to form the diversity of arts of Surabaya. Traditional art that grew due to the long historical journey against the ancient invaders, is still preserved to the present time. Traditional forms of art are many manifold. There is art of dance, music art and stage art. The people of East Java have many traditions that are still alive and exploited and proud of their supporters. These traditions, among others, form various art forms that have many heirs, whether active heir or artist or passive heir or art connoisseurs further in Surabaya City Government, Budaya Kearifan Lokal Surabaya, without year, p. 9.

5 Suripan Hadi Hutomo, "Anelusur Asal lan Tegese Tembung Ludrug”, in Panyebar Semangat No. 18, 19 April 1989, Surabaya. dancing on stage. ${ }^{6}$ From the Art Book of "Seni Tradisi Budaya Daerah" (Data of East Java Regional Art Organization) published by the Education and Culture Office of the Province of East Java (1998), it can be seen that some cities in East Java, especially the cultural areas of Arek and Pandalungan, still have many art groups of ludruk. As a Javanese traditional art performance, ludruk has conventions related to wewaton (basic show), paugeran (rules of the show), and pakem (standard) in every show. Recognized or not, today's ludruk art performance is one of the traditional performing arts that become "victim" of the changing in the taste of art and public taste for the type of spectacle and entertainment. Today is in contrast to the 1950s and 1960s when traditional art performances were still triumphant. Now ludruk receives less attention in the public heart. In art history, ludruk has a long history. Suripan Sadi Hutomo presented ludruk history systematically based on the Dutch colonial government's manuscripts, dictionaries, articles and reports. ${ }^{7}$

The history of ludruk, based on written data, originated from Lerok Bandan, the art of folk performances which were staged in the yard and supported by simple musical instruments, such as kendang and jidor (kinds of percussion). The presentation of Lerok Bandan performance was supported by the stage performers who presented the mystical scene, supernatural or inner power. This show was often used as a treatment for sick children. Historically, this ludruk art performance was thought to have appeared in the 13th and the $14^{\text {th }}$ centuries or even until the 16 th century. Then it was known with the term Sandiwara

\footnotetext{
6 Fuji Rahayudan Septina Alrianingrum, "Perkembangan Seni Pertunjukan Ludruk Di Surabaya Tahun 1980 1995" (Historical review of Kartolo CS) in AVATARA, eJournal Pendidikan Sejarah Volume 2, No. 2, June 2014 50, Jurusan Pendidikan Sejarah Fakultas Ilmu Sosial, Universitas Negeri Surabaya, p. 53.

7 Suripan Hadi Hutomo, “Anelusur Asal lan Tegese Tembung Ludrug”, in Panyebar Semangat No. 18, 19 April 1989, Surabaya.
} 
Lerok which was accompanied with simple gamelan music, but inside it there was kidung. This form of performance still presented the mystical element, supernatural forces, inner power and a series of other Javanese religious systems. After that, there came the terms Lerok Besut and Lerok Ngamen which received a great welcome from the community. The players were often invited by those who were making celebration, such as wedding ceremony, circumcision, ngruwat (release vows), and others. ${ }^{8}$ The most recent appearance was the form of lerok berlakon, that is, the presentation of art performance supported by story. Lerok berlakon enjoyed its tremendous popularity after the Japanese era and post-independence of the Republic of Indonesia.

D. Djajakusuma, during the workshop on ludruk in Surabaya in 1987, said that in the early 19th century, ludruk word was familiar in the society of East Java. Based on these data, Suripan Sadi Hutomo concluded that in the 17 th century the word ludruk, meaning clown, became the folk art. The problem is on how to trace the form and character of the folk art that cannot be reconstructed. As a local cultural product, ludruk is a typical performing art for the people of East Java. As a typical local cultural product, ludruk has a character that is not found in other traditional arts. Sedyawati states that ludruk, as a traditional drama, has a distinctive characteristic, among others: ludruk performances are performed with improvisation, without preparation of manuscript; ludruk has a standard / convention (there is a cast of woman played by man); it has a distinctive song, in the form of jula-juli; it is accompanied by gamelan music with slendro, pelog, laras slendro and pelog; the show is opened with ngremo dance; there is a bedayan scene; there is a scene of comedy / slapstick; there is a travesti interlude, the play is drawn from the folklore, history, and everyday life;

\footnotetext{
8 Henrikus Supriyanto, LudrukJawa Timur: Pemaparan Sejarah, Tonel Direksi, Manajemen, Himpunan Lakon, 2001, Surabaya, PT. Bina Ilmu, p. 11.
}

there is kidungan, either kidungan with remo dance, kidungan with bedayan, kidungan with comedy, and kidungan with and scenes). ${ }^{9}$

Kasemin (1999: 19-20) states that the staging structure of ludruk from the early age of independence until now has not undergone a significant change. This means that the staging structure from the beginning of ludruk art performance until now has been followed by generations. ${ }^{10}$ The ludruk staging structure is:

1. Opening. It is filled with ngrema dance attractions.

2. Bedayan attraction. It is in the form of travesty performance with a light dance while singing jula-juli song.

3. Comedy scene (slapstick). It is in the form of a comedy performance that presents a kidungan followed by some other comedians. They then make dialogue with humorous material.

4. Presentation of plays or stories. This section is the essence of the performance. It is usually divided by several acts and each act is further divided into several scenes. On the sidelines of this section is usually filled with a dash in the form of a travesty performance by singing jula-juli song.

\section{Advancement of Culture and Corruption}

\section{Eradication}

Based on the philosophical foundation of the Law of the Republic of Indonesia Number 5 of 2017 on the Advancement of Culture (Law No. 5-2017), it is stipulated that the state advances the national culture of Indonesia in the midst of world civilization and makes culture as an investment to build the future and civilization of the nation for the

\footnotetext{
Henrikus Supriyanto, Lakon Ludruk Jawa Timur, 1992, Jakarta, Gramedia Widia Sarana Indonesia, p. 2324.

10 Kasiyanto Kasemin, Ludruk Sebagai Teater Sosial: Kajian Kritis Terhadap Kehidupan, Peran, dan Fungsi Ludruk Sebagai Media Komunikasi, 1999, Surabaya, Airlangga University Press, p. 19-20.
} 
realization of national goals as mandated by the 1945 Constitution of the Republic of Indonesia. Promoting national culture is one way of achieving the national goals of Indonesia. The national goals related to this research are embodied in Article 32 of the 1945 Constitution of the Republic of Indonesia, that is, the state promotes the national culture of Indonesia in the midst of world civilization by guaranteeing public freedom in maintaining and developing cultural values. As the culture develops, the law that is living in society can achieve the highest legal objective, that is, legal justice.

The law serves as the protection of human interests. In order for human interests to be protected, the law must be implemented. The implementation of the law may take place normally and peacefully, but a violation of the law may also occur. ${ }^{11}$ In this case, the law that has been violated is the legislation related to corruption. It is through law enforcement that this law will become something real. When law enforcement through ludruk is done, the advancement of culture ${ }^{12}$ can be focused more on the use of culture and the guidance of culture 13

The use of culture related to ludruk can strengthen the ideology, politics, economy, social, culture, defense, and security of a country. If ludruk, as a local culture, is performed, the nature of corruption will be more easily absorbed by society. Discussion of corruption will not be shown with normative explanations but with everyday language. Ludruk, as a local culture, will be part of the

\footnotetext{
11 Sudikno Mertokusumo, Mengenal Hukum, 2010, Yogyakarta, Cahaya Atma Pustaka, p. 207.

12 Article 1 paragraph 3 of LAW No. 5-2017, that the promotion of culture is an effort to improve Indonesian cultural resilience and cultural contribution in the midst of world civilization through the protection, development, utilization, and development of the culture.

13 Article 1 Paragraph 7 of Law No. 5-2017, that coaching is an effort to empower human resources, culture, cultural institutions, and cultural regulation in improving and expanding the active role and initiative of the community.
}

modernization of cultural advancement. The modernization can be divided into: ${ }^{14}$

a. Ludruk performance as a symbolic classification

Ludruk helps its participants (both players and viewers) to understand the movements of modernization within the framework of a "symbolic classification" which is meaningful and assertive. Here, Peacock uses two classification schemes. The first is the cosmological scheme, which distinguishes the characteristics of soft and rough behavior. For example, in distinguishing between Javanese kromo and ngoko, puppet show and ludruk performance, gentle knight and giant, smooth speech as usually associated with Central Java culture and cablak / nyrocos (talkative) of East Java. The second is the ideological scheme, which distinguishes between the modern, advanced, or progressive attitude and the old (conservative) attitude towards the modernization process, for example, in distinguishing between watching a movie and watching a puppet, wearing jeans and wearing a sarong, using Indonesian (or English) and using the local language. The first understanding is that when it is linked to the eradication of corruption, corruption has turned into a common crime, meaning that corruption has occurred in every aspect of life. When speaking of corruption, the delivery of honesty is in the context of soft and rough. The openness of a person in speaking honesty will influence him to keep on doing goodness without corruption. The second understanding is that when it comes to the eradication of corruption, the current ideology is the ideology that always assumes that the corruptor must be put to death.

\footnotetext{
14 In this division, the researcher refers to James L Peacock, Ritus Modernisasi Aspek Sosial \& Simbolik Teater Rakyat Indonesia, 2005, Depok, Desantara, p. 8-11 and Kathleen Azali, Ludruk: Masihkah Ritus Modernisasi?, in Jurnal Lakon Vol. 1 No. 1 Mei 2012, p. 50-51- by adding a review of law enforcement of corruption in accordance with legal studies to keep this research focused on legal research.
} 
Such thinking, according to the researcher, is wrong because when the perpetrators of corruption are sentenced to death, the purpose of law in the form of legal justice will not be achieved. Ideology in corruption is an instantaneous ideology. In the minds of ordinary people, corruption is identical to higher education whereas corruption is no longer an extraordinary crime. ${ }^{15}$ This scheme of ideology must be communicated to the public, when ludruk is taking place, so that education remains the main reason for eradicating corruption. ${ }^{16}$

\section{b. Ludruk performance as the concept of social action}

Ludruk encourages its participants to directly learn the modes of social action existing in the process of modernization. The ludruk show presents social action in every performance by "inviting its participants to identify themselves with the players who are performing certain actions to achieve certain goals," as if they were experiencing the situations that are difficult to achieve in real life. Ludruk also directs participants "to enjoy the roles, situations, goals, or

15 F Harbison dan C A Myers dalam "ManPower and Education" menyatakan bahwa "In the final analysis, the wealth of a country is based on its power to develop and to effectively utilize the innats capacity of its people. The economic development of nations, therefore, is ultimately the result of human effort. It takes skilled human agents to discover and exploit natural resources, to mobilize capital, to develop technology, to produce goods, carry on trade. Indeed, if a country is unable to develop its human resources, it can not build anything else, whether it be a modern political system, a senses of national unity, or a prosperous economy." Lebih lanjut dalam Forum Mangunwijaya, Kurikulum Yang Mencerdaskan, Visi 2030 dan Pendidikan Alternatif, 2007, Jakarta, Kompas Media Nusantara, hal. 11.

16 Education is a word that has been the benchmark of society to refer to one's intellect. Education is a conscious and planned effort to create an atmosphere of learning and learning process so that learners actively develop their potential to have spiritual spiritual strength, self-control, personality, intelligence, noble character and skills needed by themselves, society, nation and state. Moreover, in H Jawade Hafidz, Reformasi Kebijakan Pendidikan Tinggi Dalam Perspektif Hukum Di Indonesia, in Prosiding Seminar Kebijakan Perspektif Hukum, Fakultas Hukum Universitas Muhammadiyah Ponorogo 19 Agustus 2017, p. 1 . specific ways if real life provides choices, roles, situations and so on, in which one can choose." The ways created by this ludruk "is increasingly becoming a congruent type with the modernization process". When ludruk is performed as a social action, the performance must contain the nature of corruption. Corruption is a negative social act which means that corruption is committed not only individually but also involving other parties. These other parties are called social action. When someone wants to commit corruption, there must have a driving factor that corruption occurs when social action aims for personal action. By presenting corruption as a social action, people can understand that social action does not always have positive implications. Society will be invited to understand the social action of corruption in everyday life

\section{c. Ludruk performance as a show}

When ludruk involves its participants to enter the aesthetic forms that shape their deepest thoughts and feelings in ways that can stimulate the process of modernization, the ludruk will invite participants to be carried in the story line emotionally and tend to be more popular. While the cyclical (spinning), cropped-out show forms with the unsuccessful ending ends tend to be less popular. Ludruk encourages these tendencies by helping its participants to feel comfortable with all these new trends, understand these trends, and perhaps most importantly, appreciate the tortuous psychological processes that their children experience in adapting themselves with these trends. Ludruk performance with the theme of corruption is a performance that will be able to make participants more easily understand all things about corruption with a simple language. For example, people still consider corruption related to money, whereas being not on time is also part of corruption, or time corruption. 


\section{CLOSING}

\section{Conclusion}

From the discussion above, it can be concluded that the assimilation of the law with local culture of a region is not contrary to the law and this is one part of corruption eradication. In addition, by becoming part of ludruk performances, it will be in accordance with the nature of culture as set forth in Article 1 paragraph 1 of Law No. 5-2017 that culture is anything related to the creation, taste, intention, and the work of society.

\section{Suggestion}

Ludruk is a populist art and able to make the participants as legal subjects more easily understand corruption. Teaching about corruption can be channeled through ludruk as long as it remains in accordance with the nature ludruk itself.

\section{REFERENCES}

Ayu Sutarto, Reog Dan Ludruk: Dua Pusaka Budaya dari Jawa timur Yang Masih Bertahan, Makalah dalam Jelajah Budaya dengan tema: Pengenalan Budaya Lokal Sebagai Wahana Peningkatan Pemahaman Keanekaragaman Budaya, Yogyakarta 22-25 Juni 2009.

Forum Mangunwijaya, Kurikulum Yang Mencerdaskan, Visi 2030 dan Pendidikan Alternatif, 2007, Jakarta, Kompas Media Nusantara.

Fuji Rahayudan Septina Alrianingrum, PerkembanganSeni Pertunjukan Ludruk Di Surabaya Tahun 1980 - 1995 (Tinjauan Historis Grup Kartolo CS) dalam AVATARA, e-Journal Pendidikan Sejarah Volume 2, No. 2, Juni 2014 50, Jurusan Pendidikan Sejarah Fakultas Ilmu Sosial, Universitas Negeri Surabaya.

H Jawade Hafidz, Reformasi Kebijakan Pendidikan Tinggi Dalam Perspektif Hukum Di Indonesia, dalam Prosiding
Seminar Kebijakan Perspektif Hukum, Fakultas Hukum Universitas Muhammadiyah Ponorogo 19 Agustus 2017.

Henrikus Supriyanto, Lakon Ludruk Jawa Timur, 1992, Jakarta, Gramedia Widia Sarana Indonesia.

, Ludruk Jawa Timur: Pemaparan Sejarah, Tonel Direksi, Manajemen, Himpunan Lakon, 2001, Surabaya, PT. Bina Ilmu.

I Made Adi Surya Pradnya, Konsep Pravrtti Dan Nivrtti, Strategi Mencegah Korupsi Di Perguruan Tinggi, dalam Prosiding Seminar Nasional Hukum Strategi Penanggulangan Korupsi Di Perguruan Tinggi, Jurusan Hukum Fakultas Dharma Duta Institut Hindu Dharma Negeri Denpasar, 12 Mei 2017.

James L Peacock, Ritus Modernisasi Aspek Sosial \& Simbolik Teater Rakyat Indonesia, 2005, Depok, Desantara.

Kasiyanto Kasemin, Ludruk Sebagai Teater Sosial: Kajian Kritis Terhadap Kehidupan, Peran, dan Fungsi Ludruk Sebagai Media Komunikasi, 1999, Surabaya, Airlangga University Press.

Kathleen Azali, Ludruk: Masihkah Ritus Modernisasi?, dalam Jurnal Lakon Vol. 1 No. 1 Mei 2012.

Pemerintah Kota Surabaya, Budaya Kearifan Lokal Surabaya, Tanpa Tahun.

Sudikno Mertokusumo, Mengenal Hukum, 2010, Yogyakarta, Cahaya Atma Pustaka.

Suripan Hadi Hutomo, Anelusur Asal lan Tegese Tembung Ludrug, dalam Panyebar Semangat No. 18, 19 April 1989, Surabaya.

www.transparency.org/cpi pada 27 Agustus 2017.

Tomy Michael currently works as an educator at the Faculty of Law of University of 17 August 1945 Surabaya. Contact person at tomy@untag-sby.ac.id 
Tomy Michael : Law Enforcement Through 'Ludruk' And Cultural .....

Page 125-131 